\title{
Study of the Crude oil Properties of Oily seepages found in South Eastern Nigeria.
}

\author{
C. A. Nwadinigwe ${ }^{1}$, P. O. Ukoha ${ }^{1}$, I. V. Anigbogu ${ }^{1}$ and T. N. Alumona ${ }^{1,2}$. \\ ${ }^{1}$ Department of Pure and Industrial Chemistry, University of Nigeria, Nsukka, Enugu, Nigeria. \\ ${ }^{2}$ Organic Geochemistry Unit, School of Chemistry, University of Bristol, BS81TS. \\ *Corresponding author: ifyanigbo@yahoo.co.uk \\ Received 08 December 2020; accepted 25 March 20210, published online 10 April 2021
}

\begin{abstract}
ASTM D-270 method was applied in obtaining well-head crude oil samples from Awoba 8T (Rivers State), Odidi 23L, and Odidi 46S (Delta State), Eremor 1L (Bayelsa State) and Oily Seepage samples from Ugwueme (Enugu State) and Anam (Anambra State). The ${ }^{0}$ API gravity value of all the samples were $16.19^{\circ}$ and $21.47^{\circ}$ for Ugwueme seepage and Eremorcrude respectively, $22.47^{\circ}$ for Odidi $46 \mathrm{~s}$ crudeand $44.70^{\circ}, 43.84^{0}$ and $34.76^{\circ}$ for Anam seepage, Awoba $8 \mathrm{t}$ and Odidi 23L crudesrespectively, indicating heavy, medium and light crude oils respectively. All the well-head crudes and oily seepage samples studied in this work are onshore samples except Odidi 46s which is an offshore crude sample. The samples were subjected to liquid-liquid extraction using a mixture of $n$-hexane and dichloromethane $(3: 1)$. The extracted fractions were analyzed using GC-FID. The result of the analyses gave polycyclic aromatic hydrocarbons (PAHs) concentrations (mg/kg) of 7106.43 for Awoba 8T crude, 6767.41 for Odidi 23L crude, 5771.20 for Odidi 46S crude, 5191.21 for Eremor crude, 4908.04 for Ugwueme Seepage and 6983.16 for Anam seepage. The predominance of low molecular weight PAHs (LMWPs) over the high molecular weight PAHs (HMWPs) indicate that both the crude oil samples and the oily seepage samples were of Petrogenic Source. However, various ratios were obtained to identify the possible source of PAHs in the crude oil and seepage samples. Mixed sources of pyrogenic and petrogenic PAHs were also discovered with evidence of 'pyrolytic' input which may suggest some geothermal-mediated processes.
\end{abstract}

Keywords: South-South, South-Eastern, Polycyclic aromatic hydrocarbon, oily Seepage, wellhead, LMWPs, HMWPs, Petrogenic, pyrogenic, onshore and offshore.

\section{Introduction}

Crude oil is a complex compound made up of more than 17000hydrocarbon [1].The physical and chemical properties of crude oils vary from one oil location to another [2].Among the constituents of crude oil are a group of hydrocarbons known as polycyclic aromatic hydrocarbons (PAHs) $\mathrm{PAHs}$ are a category of compounds made up of two or more fused aromatic rings [3]. They are well-known, very toxic and persistent contaminants in food samples and in the environment $[4,5]$.PAHs mostly originate from either natural and/or anthropogenic combustion processes [4].Pyrogenic and petrogenic PAHs sources are classified as being anthropogenic [6, 7].For monitoring purposes, the US Environmental Protection Agency came up with a list of 16 unsubstituted PAHs that are on a priority pollutant list. These PAHs are usually termed the EPA 16 PAHs (Figure 1) and are the PAHs most commonly analyzed for $[8$, 3]. 


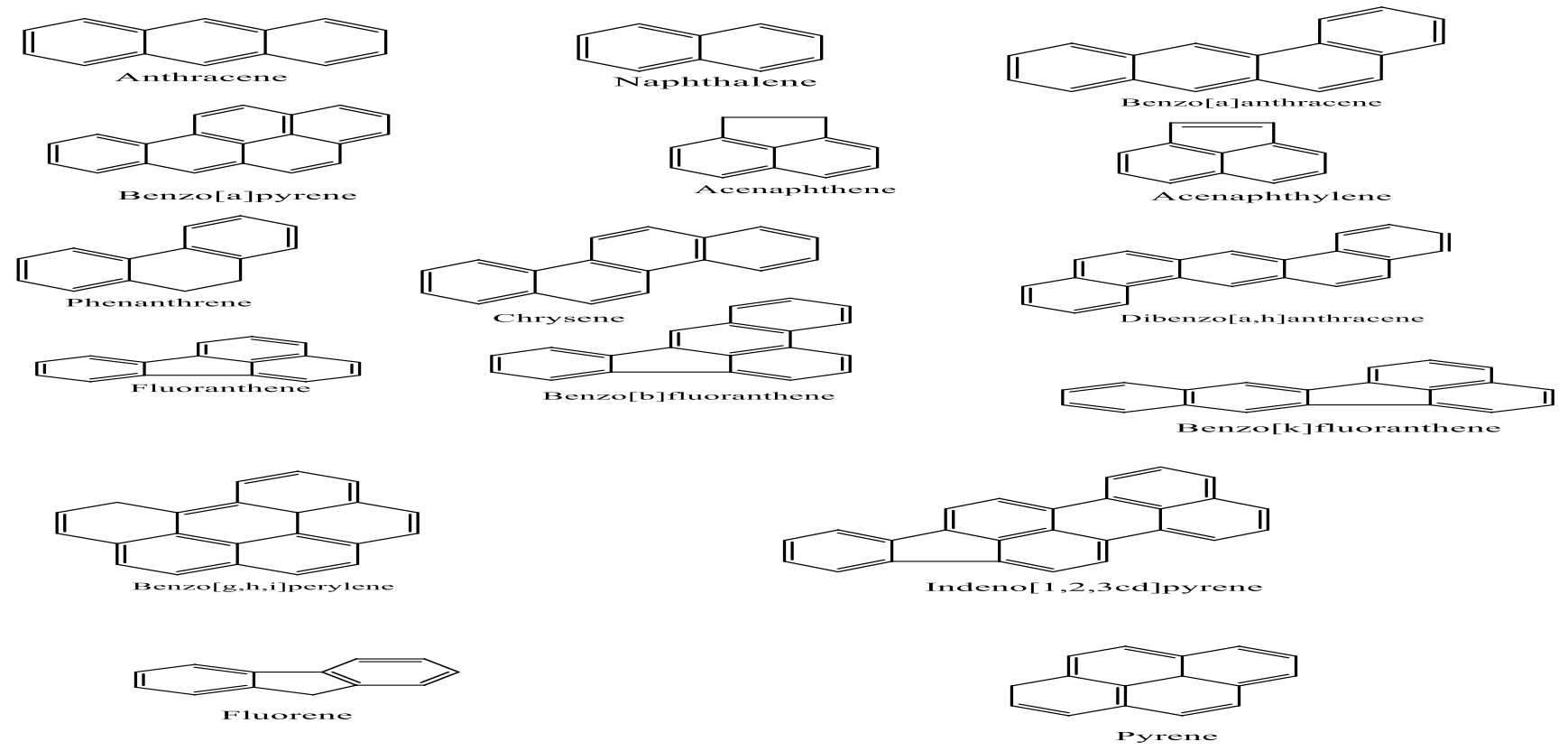

Fig. 1. Most commonly analyzed PAHs: US. EPA 16 PAHs [8].

The concentration of these 16 PAHs, and the ratios between the various compounds differ from oil to oil $[9,10]$. These 16 PAHs can be grouped into low molecular weight polycyclic aromatic hydrocarbons (LMWPs) and high molecular weight PAHs (HMWPs).Prolonged exposure to LMWPs leads to adverse health effects owing to their toxicity, carcinogenicity and mutagenicity $[11,12]$. While HMWPs are of significant concern because of their toxic properties as well as their bioaccumulation in organic tissues owing also to their lipophilic character $[6,7]$. PAHs of pyrogenic origin are the HMWPs having 4-6 rings [13].Nevertheless, the petrogenicPAHs are comprised of the alkyl-substitutedPAHs and are made up of 2-3 rings and hence are of the low molecular weight class. PAHs have and are constantly entering the environment naturally through oil seeps $[14,15]$. Natural seeps take place when liquid and gaseous hydrocarbons (Crude oil) usually trapped under a layer of rock, finds a pathway to the earth surface as it leaks out of the ground [16].PAHs are among one of the most toxic and ubiquitous environmental pollutants in this part of the world yet information on
PAHs characteristics of most of the crude types, is limited. The majority of the former environmental toxicological studies on crude oil have focused on TPH, BTEX, and heavy metals. However, toxicological studies rank PAHs above the other parameters. Comparative studies of the physicochemical; properties of the Niger Delta well-head crudes and South-Eastern seepage samples as done in this work hitherto constitute a worrying literature gap. This study was therefore designed to profile PAHs, provide information on some brands of well-head Niger Delta crude oils and South-Eastern oily seepages of Nigeria and then do a comparative study of the well-head Niger Delta crude oil and South-Eastern oily seepage sample in other to ascertain if the seepages are crude oil.

\section{Materials and methods.}

Sample areas: In this work, a total of four Nigerian well head crude oils from SouthSouth region and two oilyseepage from South-Eastern region of Nigeria were studied. The map indicating these locations are as shown in fig $2 \mathrm{a}$ and $2 \mathrm{~b}$ while table $2 \mathrm{a}$ show the summary of the sample area. 
I Chem Sor Nigeria Vol $\Delta 6 \mathrm{Nn}$ ? nn $\mathrm{n} \Delta 2 \Delta-\mathrm{n} \Delta 25$ 1วกว11

Table 1: Summary of the sample source locations of south-eastern and south-south well head crudes.

\begin{tabular}{|l|l|l|}
\hline S/No & Sample locations & States \\
\hline $\mathbf{1 .}$ & Odidi 46s (Offshore) & Delta \\
\hline 2. & Odidi 23L (Onshore) & Delta \\
\hline $\mathbf{3 .}$ & Awoba 8t (Onshore) & Porthacourt \\
\hline $\mathbf{4 .}$ & Eremor 1L (Onshore) & Bayelsa \\
\hline $\mathbf{5 .}$ & Ugwueme from Awgu & Enugu \\
\hline $\mathbf{6 .}$ & Anam from Enugwukwu & Anambra \\
\hline
\end{tabular}

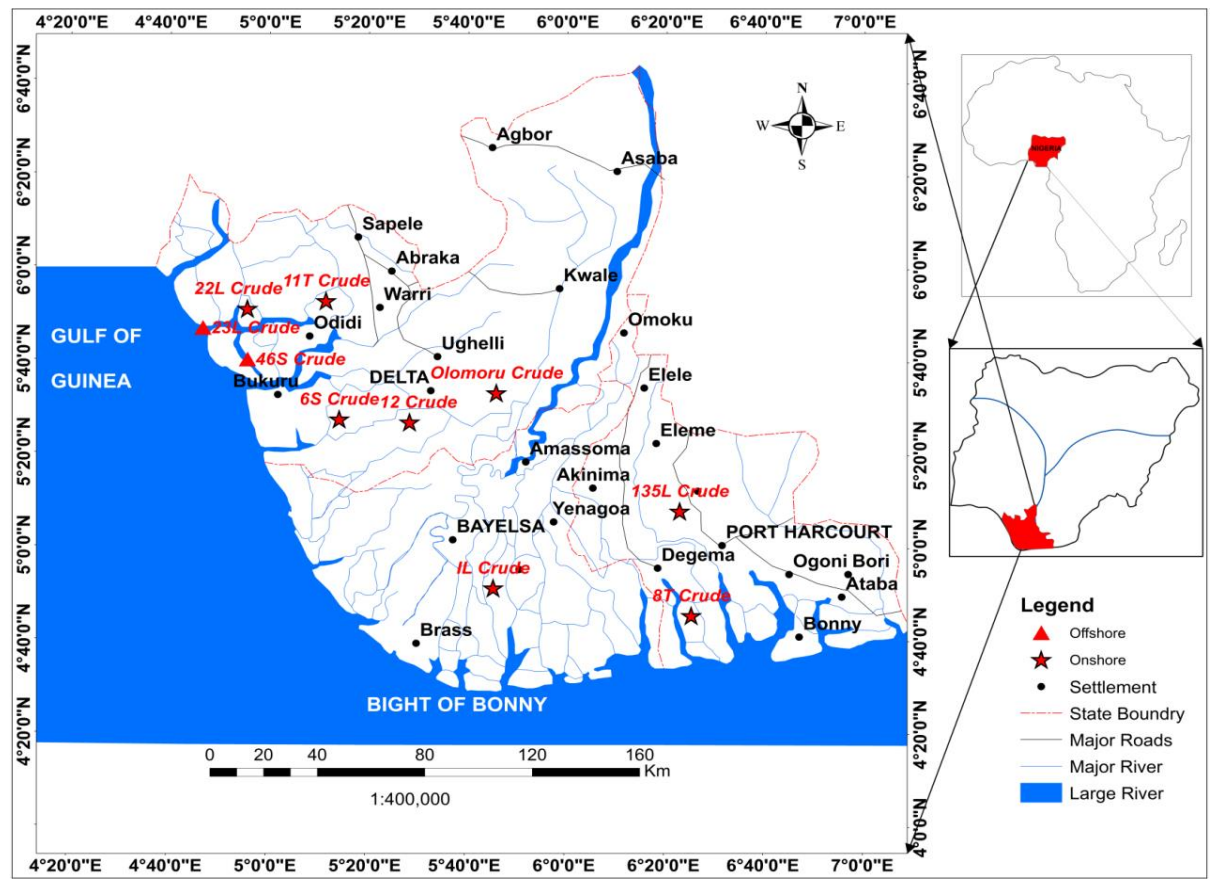

Fig. 2a: Map of south-south region of Nigeria, showing sampling area of well-head crudes.

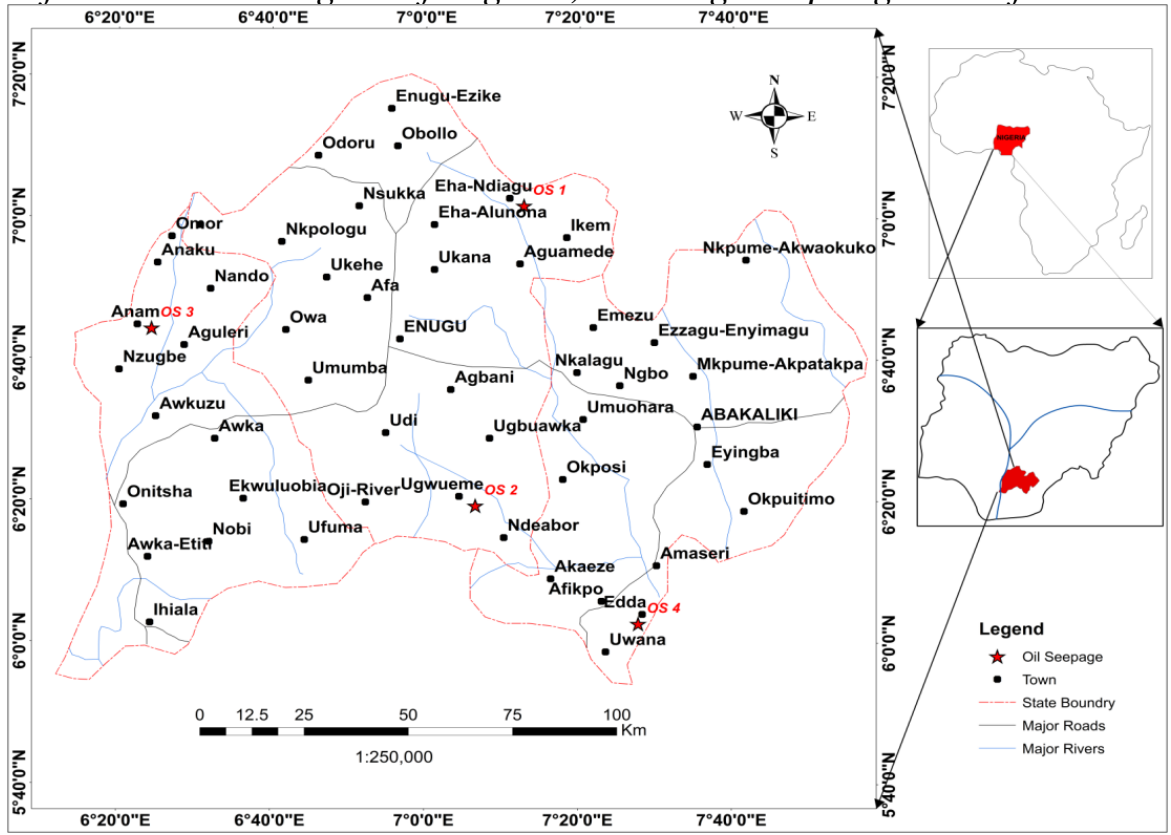

Fig. 2b: Map of south- east region of Nigeria, showing sampling area of oily seepages. 


\section{Sample collection}

Sample collection was done by applying the ASTM D-270 standard sampling procedure by Ghulam, 2013.

\section{Physical properties}

The physical properties were determined by applying the ASTM standard methods. For the API gravity and density (ASTM 1298-95), viscosity (ASTM D 445) and pour point (ASTM D 97/IP15) while for the, moisture content the themogravimetric approach was adopted.

\section{Chemical properties}

\section{PAH Extraction}

The Polycyclic aromatic hydrocarbons for all the samples were extracted by employing the modified methods of ASTM D3326 and ASTM 3415.

\section{GC-FID Analysis}

The extracted PAHs from the well head crude oil samples and oil seepage samples were analyzed by means of GC: HP 6890 powered with HP chem. Station Rev. a 09.01 [1206] software.

Column type: HP-1

Detector: FID analyzer.

\section{Results and discussion}

PAHs has been analyzed in four well-head crude samples, namely: Awoba 8t crude (onshore), Odidi 23L Crude (onshore), Odidi 46s crude (offshore), Eremor crude (onshore) and 2 oily seepage samples: Anam seepage (onshore) and Ugwueme seepage (onshore).

The results of the physical parameters and the concentration of PAHs in the samples are as presented in Table 2 and 3 respectively. The results of the physical parameters in the samples are comparable and these results are presented along with published specifications for light and heavy crude oil. The densities of Anam seepage, Awoba $8 \mathrm{t}$ crude, and Odidi $23 \mathrm{~L}$ with respective values of $0.79 \mathrm{~g} / \mathrm{ml}, 0,80 \mathrm{~g} / \mathrm{ml}$ and $0.85 \mathrm{~g} / \mathrm{ml}$ fall within the range of $0.78-0.88 \mathrm{~g} / \mathrm{ml}$ listed for light crude oils while the density of the samples from Odidi 46s, Eremor $1 \mathrm{~L}$ and Ugwueme seepage with values (in $\mathrm{g} / \mathrm{ml}$ ) of0.91, 0.92, and 0.92 respectively falls within the range of $0.88 \mathrm{~g} / \mathrm{ml}$ to $1.00 \mathrm{~g} / \mathrm{ml}$ of crude oils designated as heavy. The density values recorded for these study samples are similar and agree with density values reported by several authors $[17,18]$.
The API gravity, for the crude oil and oily seepage samples ranged from $16.19^{\circ}$ to $44.70^{\circ}$ (Table 3). The degree API of crude oils, in general, range from $\leq 10^{\circ}$ to $\geq 45^{\circ}$. API gravity $>45^{\circ}$ falls within the range of very light crude oil [19]. API gravity between $31.1^{\circ}$ to $45^{\circ}$ falls within the "light crude" category [19 20], API gravity between $22.2^{\circ}$ to $31.1^{\circ}$ falls within the medium crudes [19 20]..$^{\circ}$ API gravity less than $22.2^{\circ}$ to $10^{\circ}$ falls within the heavy crude oil [21] and ${ }^{0} \mathrm{API}$ gravity less than $10^{\circ}$ falls within the extra heavy crude oil also referred to as bitumen [20]. Therefore, Anam seepage, Awoba 8t and Odidi 23Lcrudes which are all onshore samples had respective API values of $44.70^{\circ}$, $43.84^{\circ}$ and $34.76^{\circ}$, therefore they are classified as light crude oils' however, the crude oil sample from Odidi 46s (offshore) with an API value of $22.47^{\circ}$ is classified as medium crude oil, finally Eremor 8t crude and Ugwueme seepage (both onshore) with respective API values of $21.47^{\circ}$ and $16.19^{\circ}$ are classed as heavy crude. This shows from the results obtained that, Anam Seepage which was obtained onshore has similar API gravity and density characteristics with Awoba 8t and Odidi $23 \mathrm{~L}$ crudes which were also obtained on shore and designated as light crude oils. Similarly, the density and API gravity values of Ugwueme Seepage which was also obtained onshore is similar to Eremo crude oil which is an onshore crude and falls under the class of heavy oils. From these regards, they have the same properties and this shows that the oily seepage samples represent liquid oil that are covered by land. These results are consistent with results previously reported by several authors [22, 23, and 24]. The viscosity values (cp) for Anam seepage, Awoba 8t, Odidi 23L, Odidi 46S, Eremor crude and Ugwueme seepage are 1.84, 6.90, 32.32, 92.88, 79.59 and 94.97 respectively (Fig. 3 and 4).This falls within the same range of viscosity values ranging from 0.8 to $155 \mathrm{cp}$ with crude oil API values between the range of 10.1 to $52.5^{\circ}$ reported by Osamah et al (2016)[25].

The pour point of the six samples studied in this present work ranged from $-30.5^{\circ} \mathrm{C}$ to $25^{\circ} \mathrm{C}$. The recommended pour point range for crude oils, irrespective of the type, is from $-40^{\circ} \mathrm{C}$ to $30^{\circ} \mathrm{C}$. Mean while, the observed pour point values for Anam seepage, Awoba 8t, Odidi 23L, Odidi 46S, Eremor and Ugwueme seepage are $25^{\circ} \mathrm{C},-13.5^{\circ} \mathrm{C}$, $13.5^{\circ} \mathrm{C},-24^{\circ} \mathrm{C},-24^{\circ} \mathrm{C}$, and $-30.5^{\circ} \mathrm{C}$ respectively indicating that Anam seepage with value greater than 15 have very high waxy content, Awoba $8 \mathrm{t}$ 
and Odidi 23L indicated crude oil samples within the paraffinic base, while Odidi 46s crude, Eremor Crude and Ugwueme Seepage samples with lower pour point values indicates crude oils with very low waxy content [26]. These values are within the required specification for the pour point of crude oils (Table 2) [23, 26, and 27] and serves also as a proof that the oily seepage samples are crude oil.
Moisture content in crude oil is within the range of $0 \%$ to $100 \%$. Considering the moisture content value for samples in this present work, it ranges from $0.002 \%$ to $0.006 \%$ as seen in table 2 , this implies that all the samples in this present study are of very high quality with respect to their water content values [28].

Table 2. Levels of the physical properties of the well-head crudes and oily seepage samples studied

\begin{tabular}{|c|c|c|c|c|c|c|c|c|c|}
\hline Property & Unit & $\begin{array}{l}\text { Anam } \\
\text { seep }\end{array}$ & $\begin{array}{l}\text { Awoba } \\
8 \mathrm{t} \\
\end{array}$ & $\begin{array}{l}\text { Odidi } \\
\text { 23L }\end{array}$ & $\begin{array}{l}\text { Odidi } \\
\text { 46s }\end{array}$ & Eremor & $\begin{array}{l}\text { Ugwueme } \\
\text { seep }\end{array}$ & Light crude & Heavy crude \\
\hline Density & $\mathrm{g} / \mathrm{ml}$ & 0.79 & 0.80 & 0.85 & 0.91 & 0.92 & 0.92 & $0.78-0.88$ & $0.88-1.0$ \\
\hline API gravity & o & 44.7 & 43.84 & 34.76 & 22.47 & 21.47 & 16.19 & $\begin{array}{l}31.1-45 \text { and } \\
\text { above }\end{array}$ & $10-22.2$ \\
\hline $\begin{array}{l}\text { Viscosity at } \\
15.6^{\circ} \mathrm{C}\end{array}$ & $\mathrm{Cp}$ & 1.84 & 6.963 & 32.32 & 92.88 & 79.59 & 94.12 & $0.8-155$ & $0.8-155$ \\
\hline Pour point & ${ }^{\circ} \mathrm{C}$ & 25 & -13.5 & -13.5 & -24 & -24 & -30.5 & $-40-30$ & $-40-30$ \\
\hline $\begin{array}{l}\text { Moisture } \\
\text { content }\end{array}$ & $\%$ & 0.004 & 0.006 & 0.003 & 0.003 & 0.003 & 0.002 & 0 & 100 \\
\hline
\end{tabular}

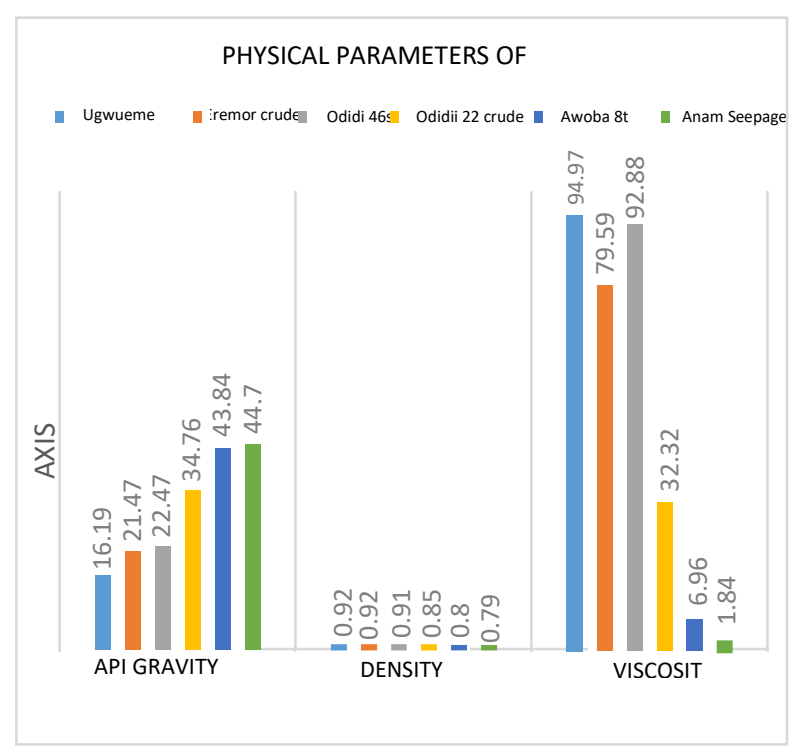

Figure 3: bar chart of degrees API gravity, density and viscosity

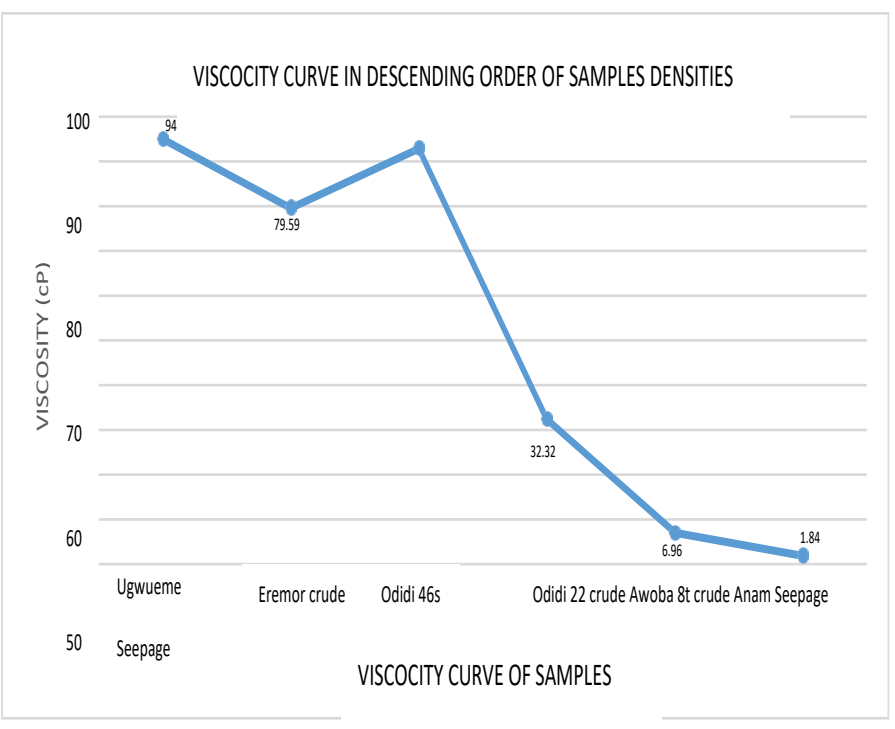

Figure 4: Viscosity curve of samples

Figure 3 shows a bar chart of degrees API gravity, density and viscosity and from this bar chart it is clearly seen that the degrees API gravity value of the samples are the exact inverse of the measure of their densities and viscosity [29]. This observation is in agreement with [24]. Therefore, viscosity is directly proportional to density, .Figure 4 
PAHs: The GC chromatograms resulting from the analysis of the six samples indicated that all the sixteen PAHs regarded as J. Che priority pollutants, were present with an additional compound (2-methyl naphthalene), but at different concentrations as represented by the peaks seen in Figure 5 - 10

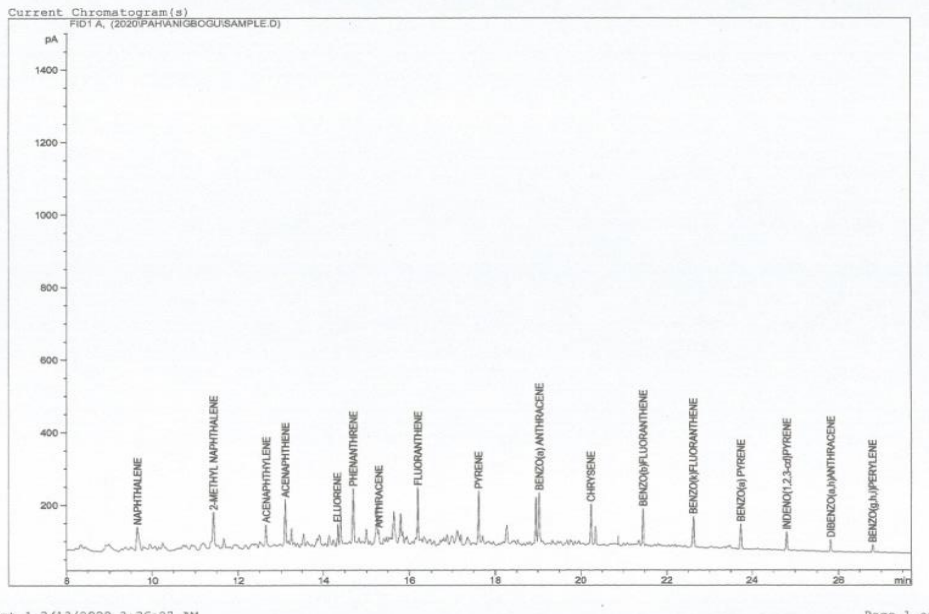

Fig. 5: GC chromatogram of the PAHs content of Odidi 23Lcrude

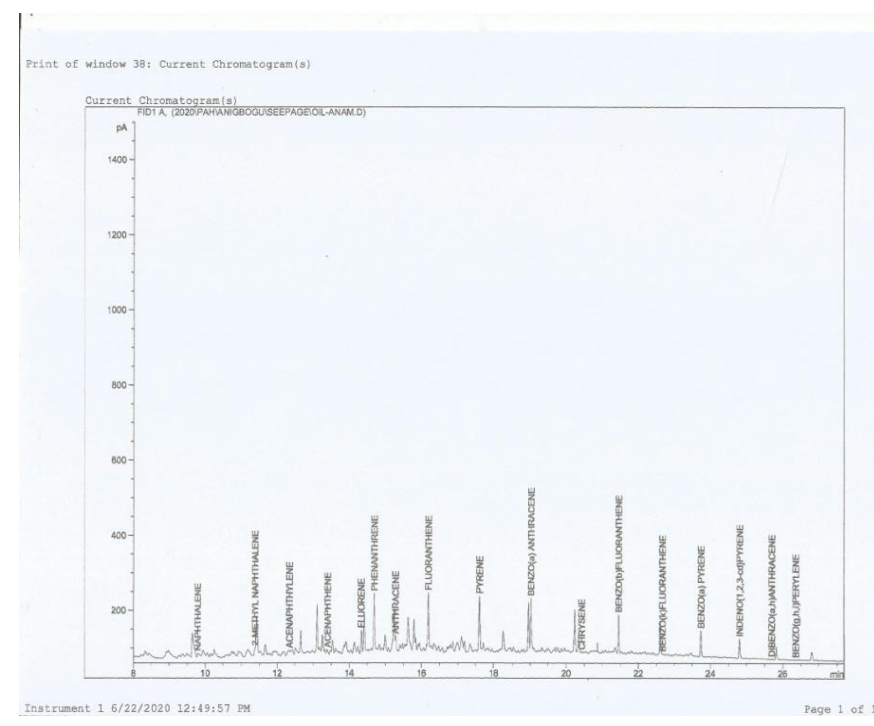

Fig. 7: GC chromatogram of the PAHs content of Eremor crude

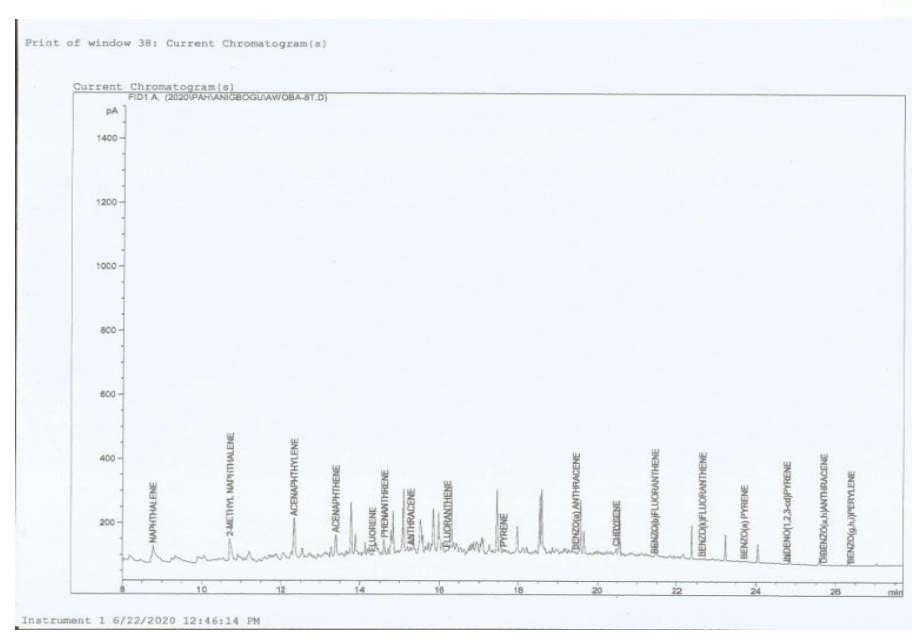

Fig. 6: GC chromatogram of the PAHs content of Awoba $8 T$ crude

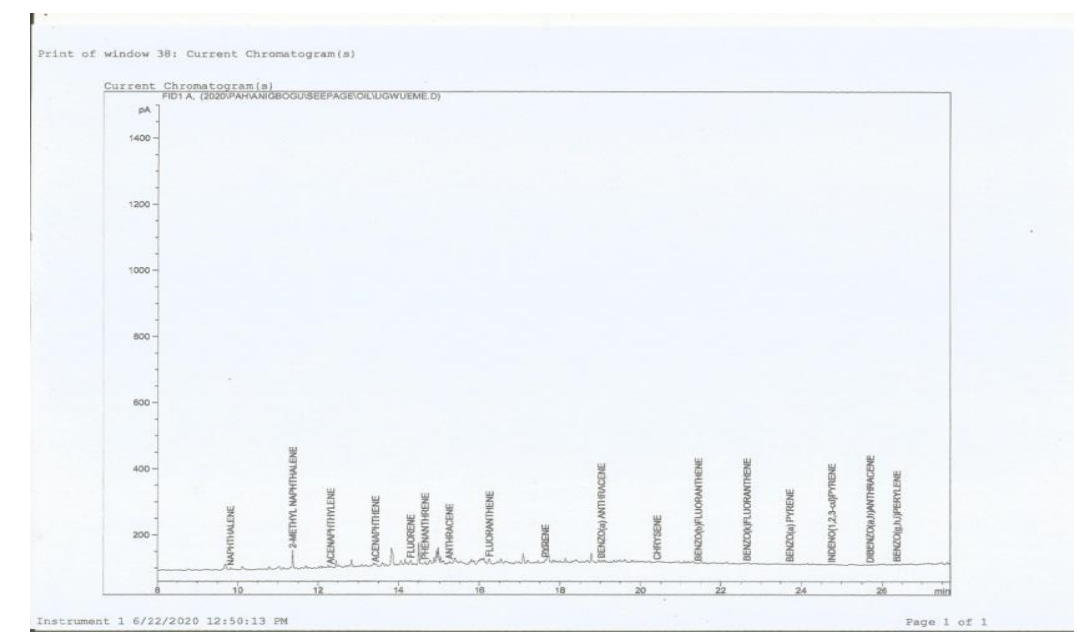

Fig. 8: GC chromatogram of the PAHs content of Odidi $46 S$ Crude 


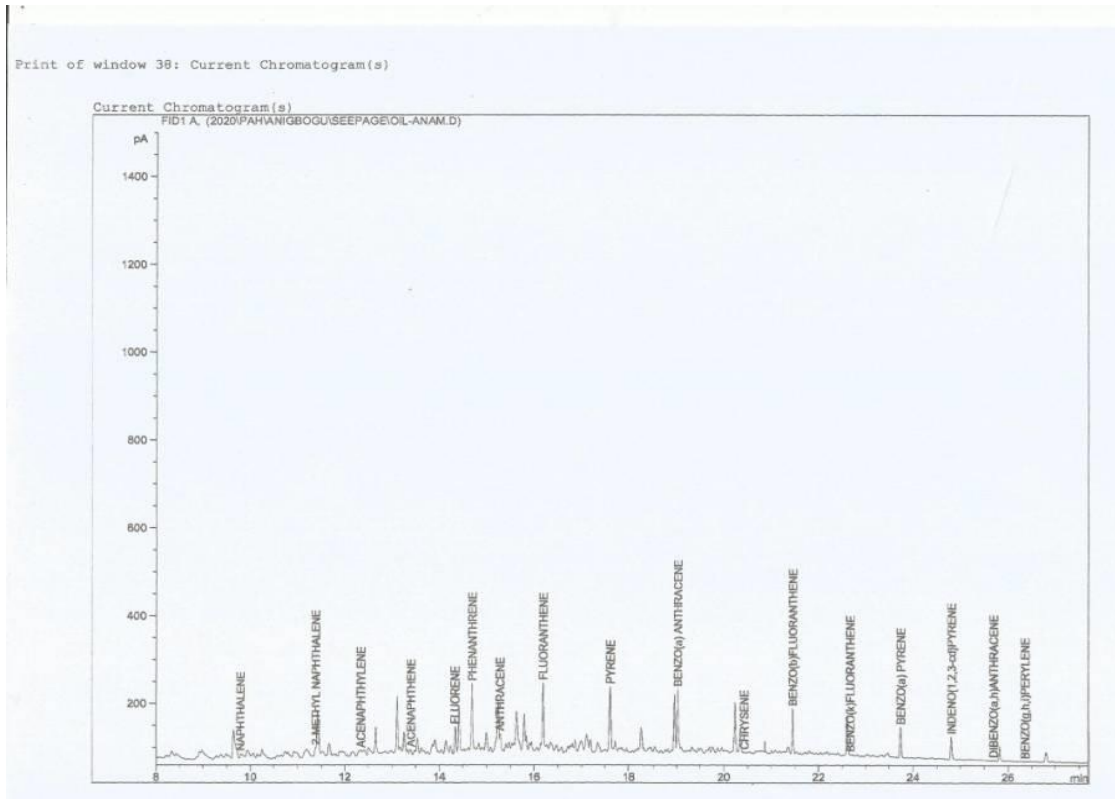

Page 1 of

Fig 9: GC chromatogram of the PAHs content of Anam seepage Anam

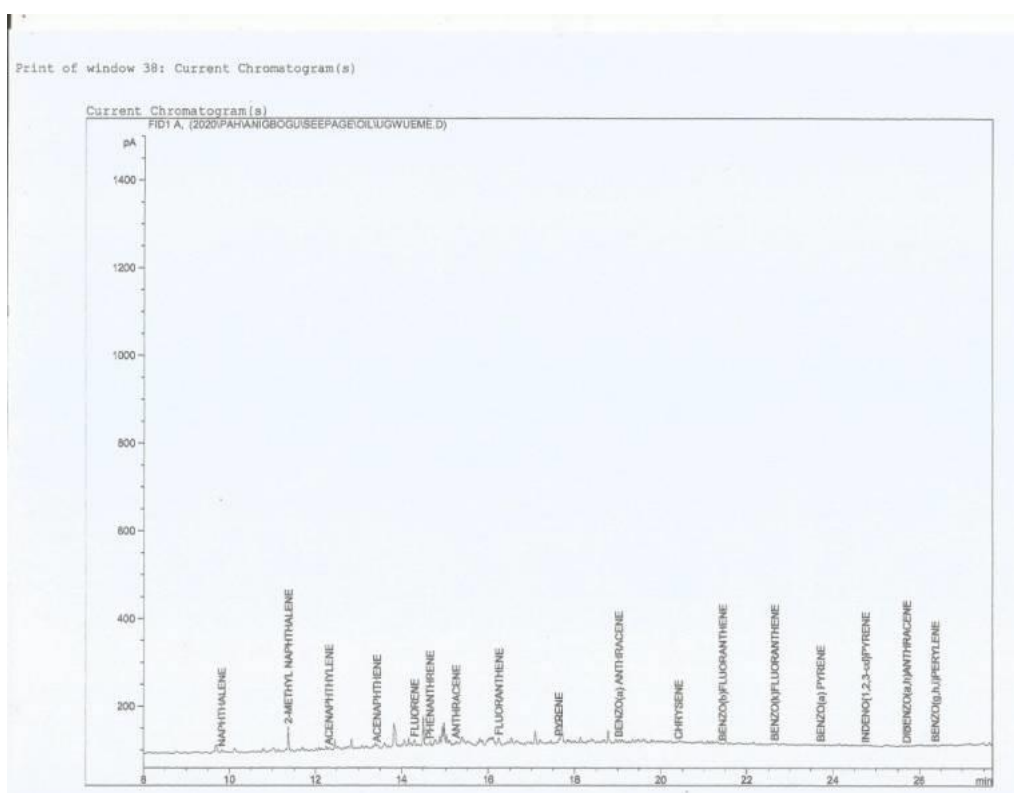

Fastrument $16 / 22 / 2020$ 12:50:13 in

Table 3: Concentrations of PAHs as obtained from the crude oils and oily seepage samples.

\begin{tabular}{|c|c|c|c|c|c|c|}
\hline PAHs in $\mathrm{mg} / \mathrm{kg}$ & $\begin{array}{r}\text { Anam } \\
\text { Seepage }\end{array}$ & Awoba 8t & Odidi 23L & Odidi 46s & Eremor & $\begin{array}{r}\text { Ugwueme } \\
\text { Seepage }\end{array}$ \\
\hline Naphthalene & 1498.21 & 1501.83 & 1465.24 & 1211.52 & 1074.78 & 1033.16853 \\
\hline 2-methyl Naphthalene & 897.12 & 900.41 & 895.58 & 644.06 & 632.31 & 625.73546 \\
\hline Acenaphthylene & 1029.54 & 1035.08 & 986.73 & 864.27 & 778.31 & 741.95021 \\
\hline Acenaphthene & 682.19 & 666.04 & 632.99 & 694.48 & 484.91 & 400.81612 \\
\hline Fluorene & 205.29 & 226.46 & 192.78 & 174.73 & 260.56 & 146.12887 \\
\hline Anthracene & 422.88 & 430.46 & 402.13 & 362.07 & 390.92 & 337.87036 \\
\hline Phenanthrene & 231.47 & 234.43 & 222.85 & 219.14 & 185.75 & 153.15379 \\
\hline Fluoranthene & 407.96 & 446.49 & 405.82 & 370.63 & 330.74 & 324.4643 \\
\hline Pyrene & 473.09 & 461.21 & 457.16 & 208.12 & 345.46 & 305.27073 \\
\hline Benzo[a]anthracene & 155.46 & 156.33 & 153.85 & 125.05 & 115.99 & 103.60309 \\
\hline Chrysene & 201.90 & 204.71 & 196.90 & 145.07 & 110.51 & 111.0954 \\
\hline Benzo[b]Fluoranthene & 102.39 & 103.98 & 100.69 & 88.62 & 85.18 & 62.93032 \\
\hline Benzo[k]Fluoranthene & 138.19 & 140.52 & 126.15 & 132.31 & 121.75 & 93.66559 \\
\hline Benzo[a]pyrene & 115.06 & 117.78 & 114.73 & 81.13 & 75.56 & 71.10783 \\
\hline Dibenzo[a,h]anthracene & 85.77 & 89.46 & 70.35 & 95.30 & 64.31 & 62.01651 \\
\hline Benzo[g,hi] perylene & 121.91 & 133.66 & 111.53 & 131.55 & 107.14 & 94.16766 \\
\hline Indino[1,2,3-cd]pyrene & 234.75 & 259.59 & 231.93 & 174.32 & 164.05 & 160.8941 \\
\hline Total $(\mathrm{mg} / \mathrm{kg})$ & 6983.16 & 7106.43 & 6767.41 & 5771.20 & 5191.21 & 4908.04 \\
\hline
\end{tabular}


The total concentrations of the PAHs in the samples ranged from $4908 \mathrm{mg} / \mathrm{kg}$ to $7106.43 \mathrm{mg} / \mathrm{kg}$ (Table 3).

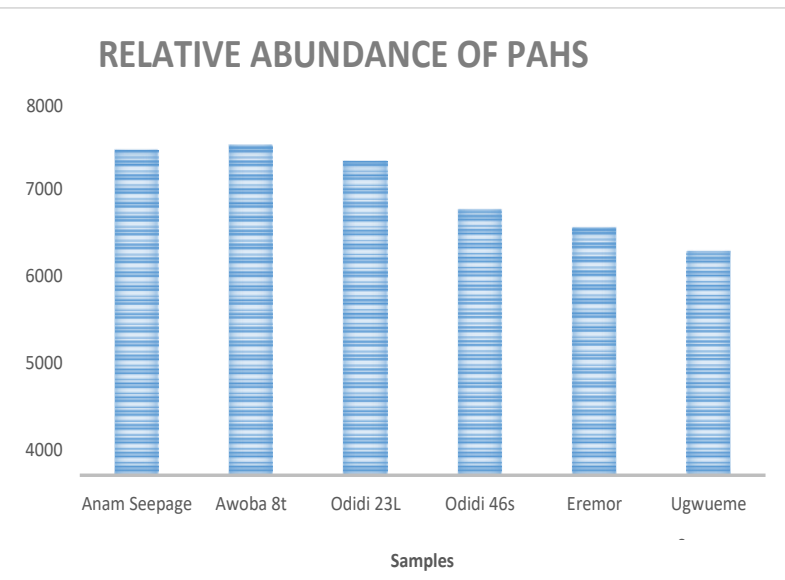

Fig 11: Relative abundance of PAHs in the samples

The light crude oils and oily seepage samples i.e. Anam seepage, Awoba 8t crude, and Odidi 23Lhad PAHs concentrations of 6983.16 $\mathrm{mg} / \mathrm{kg}, \quad 7106.43 \mathrm{mg} / \mathrm{kg}$ and $\quad 6767.41 \mathrm{mg} / \mathrm{kg}$ respectively, the medium crude sample from Odidi46s had PAHs concentration of 5771.20 $\mathrm{mg} / \mathrm{kg}$ and the heavy crude and oily seepage samples i.e. Eremor and Ugwueme seepage had PAHs concentrations of $5191.21 \mathrm{mg} / \mathrm{kg}$ and $4908.04 \mathrm{mg} / \mathrm{kg}$ respectively. Figure 11

The results indicated that the total PAHs concentrations in the light crude oils with respective API gravities of $44.7^{\circ}, 43.84^{\circ}$ and $34.32^{\circ}$ are higher than that in the medium crude having API gravity of $22.47^{\circ}$ and heavy crude oils and seepage samples having API gravities of $21.47^{\circ}$ and $16.19^{\circ}$ Figure 12 .

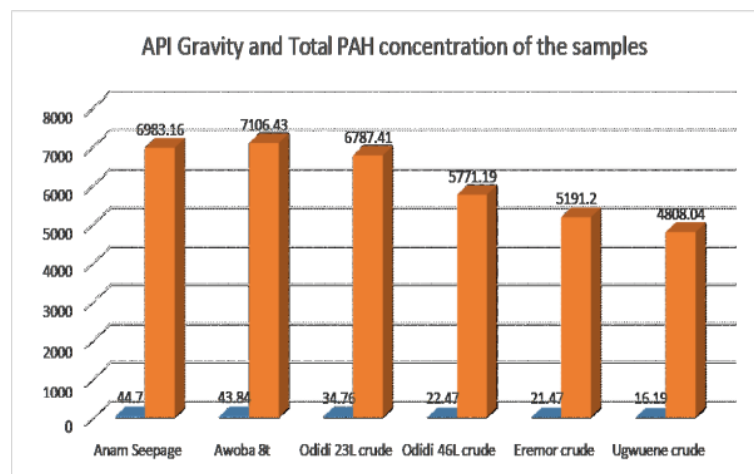

Figure 12: Total PAAH Gencentration and their degree API gravities.

These results of the oily seepages and the wellhead crudes are comparable with each other and with those reported in the literature of some Nigerian crude oils with total PAHs values that ranged from $992.7623 \mathrm{ppm}$ to 26089.3457ppm [29].The results (table 3) showed also that all ring sizes of PAHs were present in an increasing order of $2>3>4>6$ as reported by Taofik Adekoke 2019 [30].Figure 13.

Also, the total concentrations of the LMWPs were higher compared to the total concentrations of the HMWPs in both the oily seepage samples and the well-head crude samples. Figure 14 (Table 4).This observation is in agreement with that reported by several authors $[29,31]$.

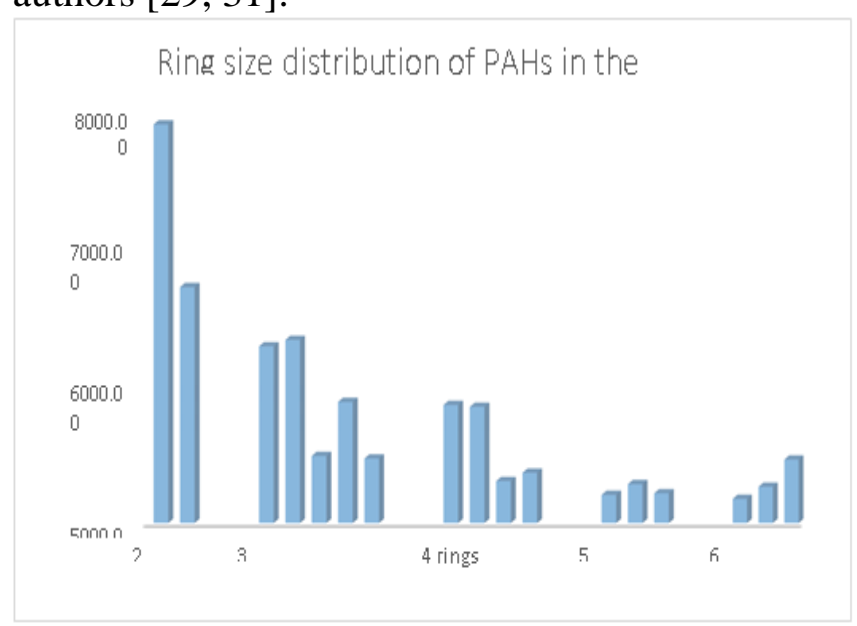

Figure 13: Ring size distribution of PAH in the study samples

Table 4 showed that Anam seepage had the same high amounts of total PAHs like Awoba and Odidi 23L when compared to Eremor crude and Ugwueme seepage. Also, Higher concentrations of LMWPs compared to the HMWPs in both the oily seepages and wellhead crude samples observed in this study is typical of hydrocarbons of petrogenic origin. This is in agreement with studies reported by [29]. Furthermore, the ratios between the LMWPs and the HMWPs were greater than one in all the samples (Table 4) which indicate petrogenic source for both the well-head crude and oily seepage samples. A similar observation was reported by [9, 29].In their reports, the ratios of LMWPs/HMWPs were >1 and typically represented pollution of Petrogenic origin. Several authors [11, 12] reported that prolonged exposure to low levels of PAHs leads to adverse health effects due to their toxicity, carcinogenicity and mutagenicity. 
J. Chem. Soc. Nigeria, Vol. 46, No.2, pp $0424-0435$ [2021]

Table 4: Total concentrations of PAHs and the ratios between the LMWPs and the HMWPs for both the well-head crude and oily seepage samples

\begin{tabular}{|l|l|l|l|l|l|l|}
\hline PAH & $\begin{array}{l}\text { Anam } \\
\text { Seepage }\end{array}$ & Awoba 8t & Odidi 23L & Odidi 46s & Eremor & $\begin{array}{l}\text { Ugwueme } \\
\text { Seepage }\end{array}$ \\
\hline Total PAH & 6983.16 & 7106.43 & $6767 . .41$ & 5771.19 & 5191.21 & 4808.04 \\
\hline LMWPAHs & 4946.69 & 4994.20 & 4799.17 & 4035.27 & 3667.53 & 3418.82 \\
\hline HMWPAHs & 2036.47 & 2111.72 & 1969.10 & 1735.92 & 1523.68 & 1389.22 \\
\hline $\begin{array}{l}\text { LMWPAHs/ } \\
\text { HMWPAHs }\end{array}$ & 2.43 & 2.40 & 2.40 & 2.30 & 2.403 & 2.50 \\
\hline
\end{tabular}

Low Molecular Weight PAHs Vs. High MolecularWeight PAHs

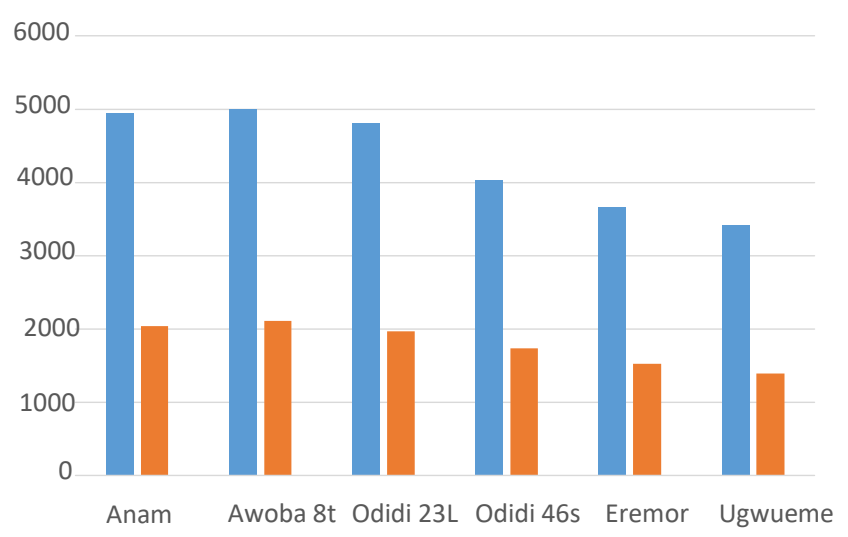

Sample Locations

-LMWPAHS "HMW PAHS

Figure 14: LMWPs vs. HMWPs

TABLE 5: DIAGNOSTIC/UNIQUE RATIOS OF PAHS IN ALL THE 6 SAMPLES

\begin{tabular}{|l|l|l|l|l|l|l|l|l|l|l|}
\hline \multirow{2}{*}{$\begin{array}{l}\text { PAH Diag } \\
\text { Ratio Unigue } \\
\text { Diag. Bario }\end{array}$} & \multicolumn{6}{|c|}{ Sampling Point } & & \\
\cline { 2 - 10 } & $\begin{array}{l}\text { Anam } \\
\text { Seepage }\end{array}$ & $\begin{array}{l}\text { Awoba } \\
8 \mathrm{t}\end{array}$ & $\begin{array}{l}\text { Odidi } \\
\text { 23L }\end{array}$ & $\begin{array}{l}\text { Odidi } \\
46 \mathrm{~s}\end{array}$ & $\begin{array}{l}\text { Eremor } \\
\text { crude }\end{array}$ & $\begin{array}{l}\text { Ugwueme } \\
\text { Seepage }\end{array}$ & Petrogenic & Pyrogenic & Pyrolytic & $\begin{array}{l}\text { Petroleum } \\
\text { Combustion } \\
\text { Source }\end{array}$ \\
\hline Flu/Pyr & 0.86 & 0.97 & 0.89 & 0.90 & 0.96 & 1.00 & $<1$ & $>1$ & & \\
\hline Phe/Ant & 0.55 & 0.55 & 0.55 & 0.61 & 0.56 & 0.45 & $>10$ & $<10$ & & \\
\hline Flu/Pyr+Flu & 0.46 & 0.49 & 0.47 & 0.64 & 0.49 & 0.52 & $\geq 0.5$ & $0.4 \& 0.5$ & & 0.4 \\
\hline Ant/Ph+Ant & 0.65 & 0.65 & 0.64 & 0.64 & 0.65 & 0.69 & $\leq 0.1$ & $>0.1$ & & \\
\hline Ind/Bghip+Ind & 0.66 & 0.66 & 0.68 & 0.24 & 0.61 & 0.63 & 0.2 & & & $\geq 0.2 \leq 0.5$ \\
\hline BaA/Chr+BaA & 0.44 & 0.433 & 0.44 & 0.46 & 0.51 & 0.48 & $>0.2$ & --- & $>0.35$ & \\
\hline
\end{tabular}




\section{Conclusion.}

The results of both the oily seepage samples and wellhead crude samples from Awoba 8t, Anam and Odidi $23 \mathrm{~L}$, are indicative of light crude oils, the sample from Odidi 46s indicate a medium crude oil while the samples from Eremor and Ugwueme are indicative of heavy crude oils. All the sixteen priority PAHs with an additional compound (2-methylnaphtalene) were present in both the oily seepages and the well-head crude samples in similar pattern for light and heavy samples alike, suggesting that both the crude and oily seepages are of similar source. Light crude oils contain higher PAH concentrations than the heavy crude oil in all study samples. The concentrations of the LMWPs were higher than the concentrations of the HMWPs irrespective of the samples being onshore or offshore. The ratio of the LMWPs/HMWPs indicate

\section{References}

1. D. Xuezhi, A. A. Ahmed, I. Muhammed, T. Shah, Q. Kalwa (2020).Remediation methods of crude oil contaminated soil. World Journal Agric \& soil science, 4,3 .

2. J. D. Udeme and I. U. Etim (2012). Physicochemical studies of Nigeria crude oil blends, 54 (3) 243-251.www.vurup.sk/petroleumcoal

3. L. Byeong-Kyu, and T. V. Van (2018). Sources, distribution and toxicity of polycyclic aromatic hydrocarbons (PAHs) in particulate matter, air pollution, $1-21$.

http://www.intechopen.com/books/air-

pollution/sources-distribution-and-toxicity-of-

polyaromatic-hydrocarbonspahs-in-particulatematter

4. V. Gerd, D. Frank, and S. Pat (2015). Profiling of polycyclic aromatic hydrocarbons in crude oil with the Agilent 1290 infinity 2D-LC solution, Research Institute for Chromatography. Energy and Chemicals, $1-11$.

5. N. E. Joshua, O. O. John, A. M. M. Titus and O. Elizabeth (2016), Determination and Distribution of polycyclic Aromatic Hydrocarbons in rivers, sediments, Journal of Environmental Research and Public Health V.1314. 1-10.

6. Y. Liu, L. Chen, Q. H. Huang, W. Y. Li, and Y. J. Tang (2009), Source apportionment of polycyclicaromatic hydrocarbons (PAHs) in surface sediments of the Huangpu River, Shanghai, China. Sci. Total Environ, 407, 29312938.

7. C. Riccardi, D. Filippo, P. Pomata, D. Di, M. Basilio, and S. Spicaglia (2013). Identification of hydrocarbon sources in contaminated soils of three industrial areas. Science Total Environ, 450, $13-21$. that both the oily seepage samples and the well-head crude samples are of petrogenic source, with all ring sizes of their PAHs present in an increasing order of 2 $>3>4>6>5$. The observed values which include the diagnostic and unique diagnostic ratios of PAHs in the study samples (Table 5):

i. Favor spetrogenic sources as well as mixed sources (petrogenic and pyrogenic) with evidence of pyrolytic input which may suggest some geothermal mediated processes.

ii. Serves as useful baseline data for oil prospecting in South eastern Nigeria

iii. Will bring understanding and remediation to pollution status due to the seeps.

These findings therefore show that the seeps in Anam and Ugwueme are actually crude oils.

8. D. M. Pampanin, and M. O. Sydnes (2013). Polycyclic aromatic hydrocarbons a constituent of petroleum: Presence and influence in the aquatic environment http://dx.doi.org/10.5772/48176.

9. J. M. Kerr, H. R. Melton, S. J. Millen, R. I. Magaw, G. Naughton, and G. N. Little (1999). Polyaromatic hydrocarbon content in crude oils around the world. Conference paper from the 1999 SPE/EPA Exploration and production environmental conference held in Austin, Texas, USA.

10. L. G. Faksness, P. J. Brandvik, and L. K. Sydnes (2008). Composition of the water accommodated fractions as a function of exposure times and temperatures. Pollut. Bull, 56, 1746-1754.

11. W. Wilcke (2000). Polycyclic aromatic hydrocarbons (PAHs) in soil- a review. Journal. Plant Nut. Soil Sci, 163, 229-248.

12. Y. Z. Zhang, S. Tao, H. Z. Shen, and J. M. Ma (2009). Inhalation exposure to ambient polycyclicaromatic hydrocarbons and lung cancer risk of Chinese population. Proceedings of the National Academy of Sciences, 106, 2106321067.

13. M. Saha, A. Togo, K. Mizukawa, M. Murakami, and H. Takada (2009). Sources of sedimentary PAHs in tropical Asian waters: Differentiation between pyrogenic and petrogenic sources by alkyl homolog abundance, Mar. Pollut. Bull, 58, 189-200.

14. Torresan (2011). What are oil and gas seeps? U.S. Department of the Interior. U.S. Geological survey.

15. J. C. Cutler (2010). Natural oil seeps and the Deep-water horizon disaster: A comparison of magnitudes. https://www.theoildrum.com/node/6552

16. M. Fingas (2011). Introduction to oil chemistry and properties. In Oil Spill Science and 
Technology. Edited by M. Fingas. Gulf Professional Publishing, Boston, 51-59.

17. Z. Wang, B. P. Hollebone, M. Fingas, B. Fieldhouse, L. Sigouin, M. Landriault, P. Smith, J. Noonan, and V. G. Thouin (2003). Characteristics of spilled oils, fuels, and petroleum products: 1 . Composition and Properties of Selected Oils. National service center for environmental publications (NSCEP).

18. C. Yang, Z. Wang, B. P. Hollebone, C. E. Brown, Z. Yang, and M. Landriault(2014). Chromatographic fingerprinting analysis of crude oils and petroleum products. In handbook of oil spill science and technology, John Wiley and sons, Inc., $93-163$.

19. M. C. Kinsey (2020). API gravity; Energy Insight,https://www.mxkinseyenergyinsights.com/ resources/refenery-reference-desk/api-gravity/ .

20. PETRO Industry News (2015). What is API Gravity?https://www.petro-online.com/breakingnews/what-is-api-gravity/33309.

21. Semih, E (2018). Petroleum processing; API Gravity,https://www.eeducation.psu.edu/fsc432/co ntent/api-gravity.

22. S. E. Ofodile, N. Boisa, C. C. Obunwo, and O. M. Frank(2018). Characteristics of oil properties from a Niger Delta crude, 8, 563.

23. G. C. J. Nmegbu, (2014). Analysis of effects of temperature on petro physical properties of petroleum reservoir rocks and fluids. International Journal of Engineering Research and Development, 10 (6) 53-61.

24. C. A. Nwadinigwe, I. V. Anigbogu, and O. T. Ujam (2014). Studies on Precipitation performance of $\mathrm{n}$-heptane and n-pentane/nheptane on $\mathrm{C}_{7}$ and $\mathrm{C}_{5} / \mathrm{C}_{7}$ asphaltenes and maltenes from $350^{\circ} \mathrm{C}$ atmospheric residuum of three
Nigerian light crudes, Journal of Petroleum Exploration and Production Technology,5 (4) 403 $-407$.

25. A. Osamah, J. Mohammad, A. Abdullahi and M. Hamed (2016). Heavy oil viscosity and density predication at normal and elevated temperatures. Journal of petroleum exploration and foundation. 6, 253-263. https://link.springer.com

26. M. C. Onojake, C. L. Osuji, and N. C. Oforka (2013). Preliminary hydrocarbon analysis of crude oils from Umutu/Bomu fields. South west Niger Delta Nigeria. Egyptian Journal of Petroleum, 22, 217-224. www.elsevier.com/locate/egypt orwww.sciencedirect.com

27. F. Merv (2011). Introduction to oil Chemistry and properties, Oil Spill Science and Technology, 15, 51-59.

28. Q. Liu, B. Chie, J. Peng, S. Tang (2019). A visual measurement of water content of crude oil Based on image curry scale Accumulated Value different.19(13) $2963 \mathrm{https} / / \mathrm{www}$. researchgate.net

29. N. Boisa., T. Ideriah and C. Okehie (2019). Evaluation of polycyclic aromatic hydrocarbons and total petroleum hydrocarbons in some Nigerian crude oils, Journal of scientific research and reports. 23(1)1-14.

30. T. A. Adedosu, O. K. Adeniyi and O. H. Adedosu (2019), Characterization and distributions of aliphatic and polyaromatic hydrocarbons in soil sand deposits area of Ondo State, Nigeria. Academic Journals. http://www.poceedings.academicjournals.org/ 4DB0442.

31. E. Magi, R. Bianco, C. Iaani, D. M. Carro (2002). Distribution of polycyclic aromatic hydrocarbons in the sediments of the Adriatic Sea. Environmental Pollution. 119, 91-9. 